\title{
Coastal Livelihood Vulnerability to Climate Change: A Case Study of Char Montaz in Patuakhali District of Bangladesh
}

\author{
Saydur Rahman ${ }^{1}$, Md. Touhiduzzaman ${ }^{2}$, Irteja Hasan ${ }^{3, *}$ \\ ${ }^{1}$ Department of Geography and Environment, Dhaka University, Dhaka, Bangladesh \\ ${ }^{2}$ Department of Geo-Information Science and Earth Observation, Patuakhali Science and Technology University, Dumki, Bangladesh \\ ${ }^{3}$ Faculty of Disaster Management, Patuakhali Science and Technology University, Dumki, Bangladesh
}

Email address:

irteja07@gmail.com (I. Hasan)

${ }^{*}$ Corresponding author

\section{To cite this article:}

Saydur Rahman, Md. Touhiduzzaman, Irteja Hasan. Coastal Livelihood Vulnerability to Climate Change: A Case Study of Char Montaz in Patuakhali District of Bangladesh. American Journal of Modern Energy. Vol. 3, No. 4, 2017, pp. 58-64. doi: 10.11648/j.ajme.20170304.11

Received: May 14, 2017; Accepted: June 6, 2017; Published: July 14, 2017

\begin{abstract}
This study was conducted at coastal Char Montaz in Rangabali Upazila at Patuakhali district of Bangladesh. Char Montaz is vulnerable to different types of destructive disasters due to its geographic location. Disasters such as floods, river bank erosion, cyclone, tornado, hail storm, water logging, salinity intrusion etc. are gradually intensifying by climate change and composing risks for the coastal people in Char Montaz. The study is concerned with climate change related risks and hazards that affects the inhabitant's livelihood of the study area. The study findings demonstrated that the climate change has affected the $70 \%$ people's agricultural livelihood in many ways. It has also created a state of unemployment among the people of coastal communities. As a result, the affected people are losing their means of livelihoods and forced to take several alternative means of livelihoods to cope with the adverse impact of climate change related disasters. The study identifies the livelihood adaptation strategies adapted by the affected communities in Char Montaz area. The present paper exhibits that the coastal community people try to solve their problems through adopting and exploring alternative employments.
\end{abstract}

Keywords: Climatic Change, Climate Change Impact, Disaster, Coastal Livelihood, Bangladesh

\section{Introduction}

Climate change is not only a regional or national issues but also a global concern, especially since the international forums urge to take immediate collaborative actions to meet the challenges of negative impact to climate change "[3-4]". Climate change contributes to increase frequency and severity of disasters with adverse impacts on humans, natural ecosystem and quality of human survival "[8], [6]". Due to a disaster poor people suffer from malnutrition as they fail to procure food "[9]". Deforestation, over fishing, over grazing, salt built up, water borne diseases from irrigation, endangered wild life from loss of habitat, loss of genetic diversity, water pollution, air pollution and climate change are related to each other and having impacts on food production, lives and livelihoods on the people of Bangladesh, especially in coastal regions of Bangladesh "[10]".

Due to geo-political and territorial location, Bangladesh is widely considered to be one of the most climate vulnerable countries in the world which also has a very high population density "[5]". The coastal region of Bangladesh experienced frequent natural and human induced disasters including sea level rise, cyclones, storm surge, flooding, land erosion, water logging, and salinity intrusion in soil and water because of extreme variability of climate change which cause loss of life, damage the infrastructure and economic assets, and adversely affect the livelihoods of people especially the poor, vulnerable and destitute living in environmentally fragile areas "[1]". The combination of a high level of poverty, and a depleted ecological system increase the country's vulnerability to the impacts of climate change "[11]". The study area is Char Montaj, Rangabali Upazila under Patuakhali district which is located to the proximity to the Bay of Bengal as a result different climatic disaster such as severe cyclone and cyclone driven storm surges, river bank erosion, tidal flooding, and saline water intrusion become very common phenomena in this area. This areas experienced the devastating impact of cyclone Sidr and Aila in 2007 and 2009 respectively "[12]". The devastation of the 
cyclone Sidr was huge in agriculture sector in the study area. According to the assessment of Ministry of Disaster Management and Relief, about $80 \%$ people were affected by the cyclone Sidr and many of them became helpless after this cyclone. Peoples live in this area also suffer more due to high salinity problem. To cope with the climate change, the peoples of this area are also taking alternative adaptation measures From several studies "[8-11]" it is revealed that the community based climate change risks reduction strategies and households and individual coping strategies with the existing socio-economic and geographical setting of disaster affected people (including women) have always been overlooked.

So, this study has given an attention to assess the impact of climate change and nature of vulnerability of coastal people's livelihood due to climate change -and especially to the vulnerability of their low-income population. Besides these, the study also concentrates on the impact of climate change in agriculture sector and to find out the nature of alternative livelihood options that minimize rhe individuals vulnerability among the rural marginal people of Char Montaz area.

\section{Methodology}

To fulfill the research objectives of this study, this study were collected both primary and secondary data. In order to conceptualize the climate change related terms, secondary data were collected from books, journal articles and reports, different government and non- government organizations reports which helps to primary data collection. Both qualitative and quantitative data such as Key Information Interviews, Focus Group Discussions and Individual Level Questioner Survey were also conducted very carefully. Key informant interviews helped to get answers of climate change effects, areas vulnerability on climate change, impact of climate change on people's life and livelihood, choice of alternative livelihood approach to cope with climate change. On the other hand, FGDs were served the purpose of not only to understand the present statues of the area but also to get answer of the following research questions such as the study area's vulnerability to climate change, impact of climate change on livelihoods, impact of climate affected services on the quality of life and how the situation of climate impact can be improved in coastal belt of the study area. After collected both the qualitative and quantitative data, it were cross checked to secondary data and after analyzing these types of data with the help of Microsoft office 13 and ArcGIS 10.3.

\section{Selection of the Study Area}

This study was conducted at Char montaz Union, Rangabali upazila in Patuakhali district (Figure 1). Since the study areas are located to the proximity to the Bay of Bengal as a result severe climatic common phenomena were exist in the study area. This union is rounded by Bura Gauranga River and after crossing this area the Bura Gauranga River meet with Bay of Bengal in southern part of this area. The area experienced by the devastated impact of cyclone Sidr and Aila in 2007 and 2009 respectively. The devastation of the cyclone Sidr was huge in the area. According to the assessment of Ministry of Disaster Management and Relief, about $80 \%$ people were affected by the cyclone Sidr and many of them were became helpless after this cyclone.

\section{Results and Discussions}

\subsection{Climate Change Trend in the Study Area}

Climate change is a regular issue and it is found that climate change is increasing the frequency and intensity of natural disaster in the study area. This is affected the human's life and livelihood of Char Montaz area. From personal interview and focus group discussion, the result comes out that increase soil saline in many times than before and as a result reduce the crop production for many times than before. Increase the heat than before. Erratic rainfall and cold occur. Before 20-25 years six seasons could be defined, but at present time only three seasons has been defined. Without it due to climatic pressure increase the frequency of cyclone, storm surge, flood, salinity, drought, excessive rainfall, high tide, hail storm, riverbank erosion, water logging, pest attack etc. The community people's perception about climatic hazard are shown the following figure 1

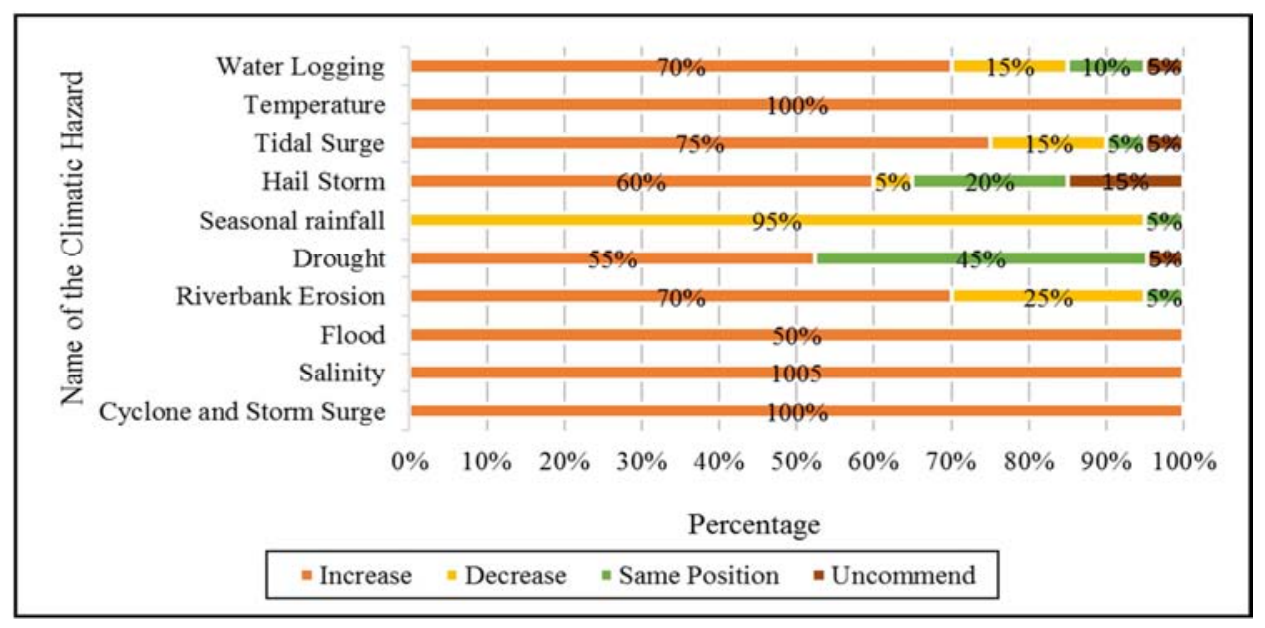

Figure 1. Community people's perception about climatic hazard. 


\subsection{Disaster History of the Study Area}

The main disaster and hazard of Char montaz are cyclone, storm surge, flood, salinity, drought, excessive rainfall, high tide, hail storm, riverbank erosion, water logging, pest attack. Here natural disasters are the regular matter and as a result of increasing vulnerability, loss of agricultural crops and change the people's livelihood pattern are very common phenomenon in the study area. The worse condition is that general people loss their livelihood option. Char Montazis a disaster prone area where disaster occurs all the year round. River bank erosion can create a large disaster for that area. The disaster history of Char Montaz are given below in following table (table 1)

Table 1. Disaster history of Char Montaz.

\begin{tabular}{|c|c|c|c|c|c|c|c|c|}
\hline \multirow[b]{2}{*}{ Sl. No. } & \multirow[b]{2}{*}{ Disaster Type } & \multirow[b]{2}{*}{ Year } & \multicolumn{6}{|l|}{ Loss (\%) } \\
\hline & & & Life loss & House damage & $\begin{array}{l}\text { Agricultural } \\
\text { crops loss }\end{array}$ & $\begin{array}{l}\text { Livestock } \\
\text { loss }\end{array}$ & $\begin{array}{l}\text { Fish production } \\
\text { loss }\end{array}$ & $\begin{array}{l}\text { Vegetation } \\
\text { loss }\end{array}$ \\
\hline 1 & Cyclone and storm surge & 1970 & 20 & 40 & 80 & 30 & 20 & 20 \\
\hline 2 & Cyclone and storm surge & 1988 & 1 & 70 & 60 & 40 & 45 & 50 \\
\hline 3 & Cyclone and storm surge & 1991 & 1 & 10 & 85 & 55 & 70 & 50 \\
\hline 4 & Sidr & 2007 & 2 & 30 & 100 & 80 & 45 & 85 \\
\hline 5 & Aila & 2009 & - & 10 & 80 & 60 & 70 & 90 \\
\hline 6 & Mahasen & 2013 & - & 5 & 50 & 30 & 40 & 55 \\
\hline 7 & River bank erosion & 1991 & - & 60 & 20 & - & 50 & - \\
\hline 8 & Riverbank erosion & 2002 & - & 10 & 30 & - & 45 & - \\
\hline 9 & Riverbank erosion & 2004 & - & 5 & 70 & - & 30 & 10 \\
\hline 11 & Flood & 1987 & 5 & 30 & 40 & 20 & 10 & 20 \\
\hline 12 & Flood & 1988 & - & 25 & 80 & 40 & 60 & 10 \\
\hline 13 & Flood & 1998 & 6 & 10 & 70 & 60 & 80 & 90 \\
\hline 14 & Flood & 2004 & - & 5 & 65 & 50 & 85 & 80 \\
\hline 15 & Flood & 2007 & - & 5 & 70 & 20 & 60 & 60 \\
\hline 16 & Drought & 2014 & - & - & 40 & 30 & 70 & 30 \\
\hline 17 & Salinity & \multicolumn{7}{|c|}{ Due to salinity problem every year crop reduce gradually } \\
\hline
\end{tabular}

(Source: Upazila Office, Rangabali).

\subsection{Climatic Hazard Index}

The community people in the study area are suffering from adverse impacts of climatic risks. These risks affect their lives in many ways, including their livelihood. The local risks in the study area were identified through a PRA exercise using focus group discussion, mapping and Calendar as tools. A brainstorming process was initiated and participants were requested to list the major risks in their respective area. After identifying the risks, the participants were asked to classify the risks that has impact on their livelihood. Finally, the risks were ranked by the participants, based on their frequency, intensity and severity. After analyzing the question it is found that the people in the study area mainly affected by salinity and it got heights score (Hazard score was calculated within 10) and hail storm got lowest score (figure 2).

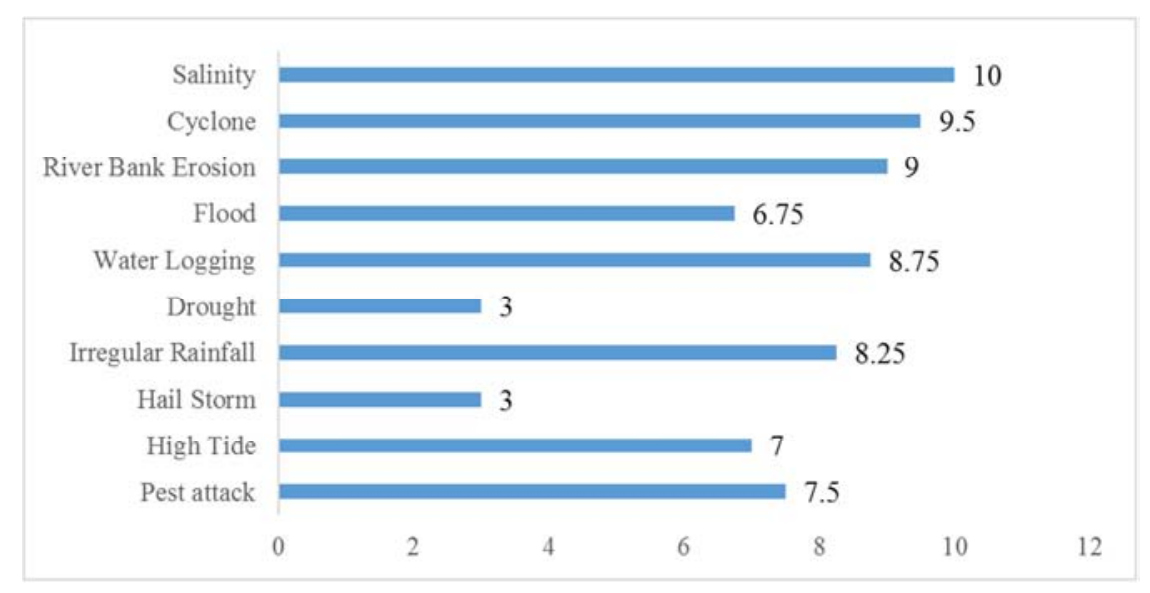

Figure 2. Hazard scoring in the study area.

\subsection{People's Livelihood}

The study found that majority of the people of the respondents are illiterate and their socio-economic condition is not up to well. The people's lives in this area mostly related with agriculture, fishing and labor work. From FGD it is found that about Thirty (30\%) people's main livelihood is agriculture, twenty three $(23 \%)$ peoples related with fish catching, $28 \%$ are agricultural labor and others related with different works such as non-agricultural wage labor, small 
treading etc. The following figure 3 showed the peoples livelihood in Char Montaz area.

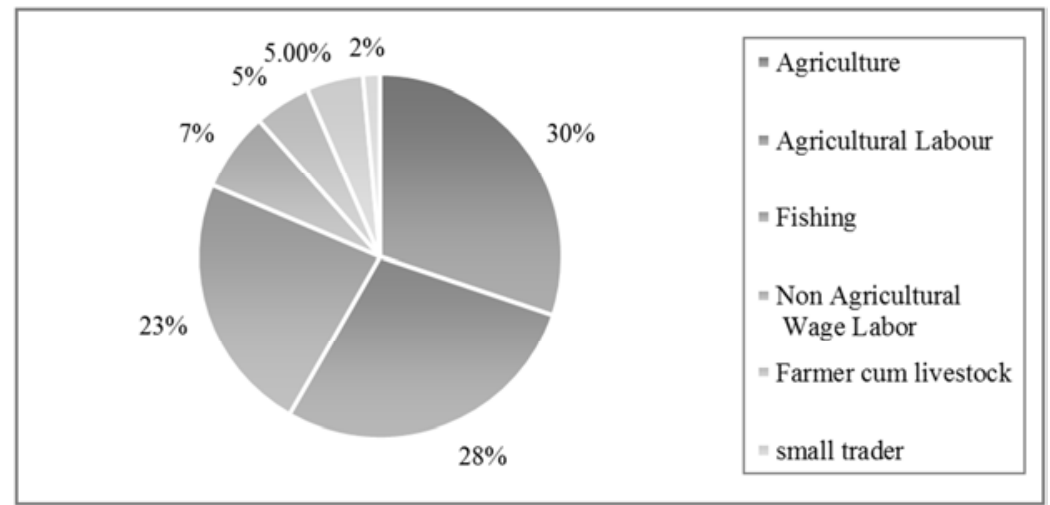

Figure 3. People's livelihood in Coastal Char Montaj Area.

\subsection{Agricultural and Hazard Seasonal Calendar}

The study found that the people in the study area face many climatic hazards impact in their livelihood sector. From FGDs it is also found that the main livelihood options are agriculture sector. The major climatic hazard that people face in their livelihood sectors are- salinity, cyclone, storm surge, flood, river bank erosion, drought, irregular rainfall, hail storm, high tide, water logging, pest infestation. Among these cyclone, flood and storm surge were considered the main risks affecting almost all livelihood sectors of the area, including agriculture, fisheries, livestock and small tread. The other main risks adversely affecting the local livelihood sectors identified are river bank erosion, drought, irregular rainfall, hail storm, high tide, water logging, and pest infestation. From the study it is also found that different types of hazards has different vulnerable sector. After analyzing the respondent opinion, this research made agricultural and hazard seasonal calendar that is given in following figure (figure 4).

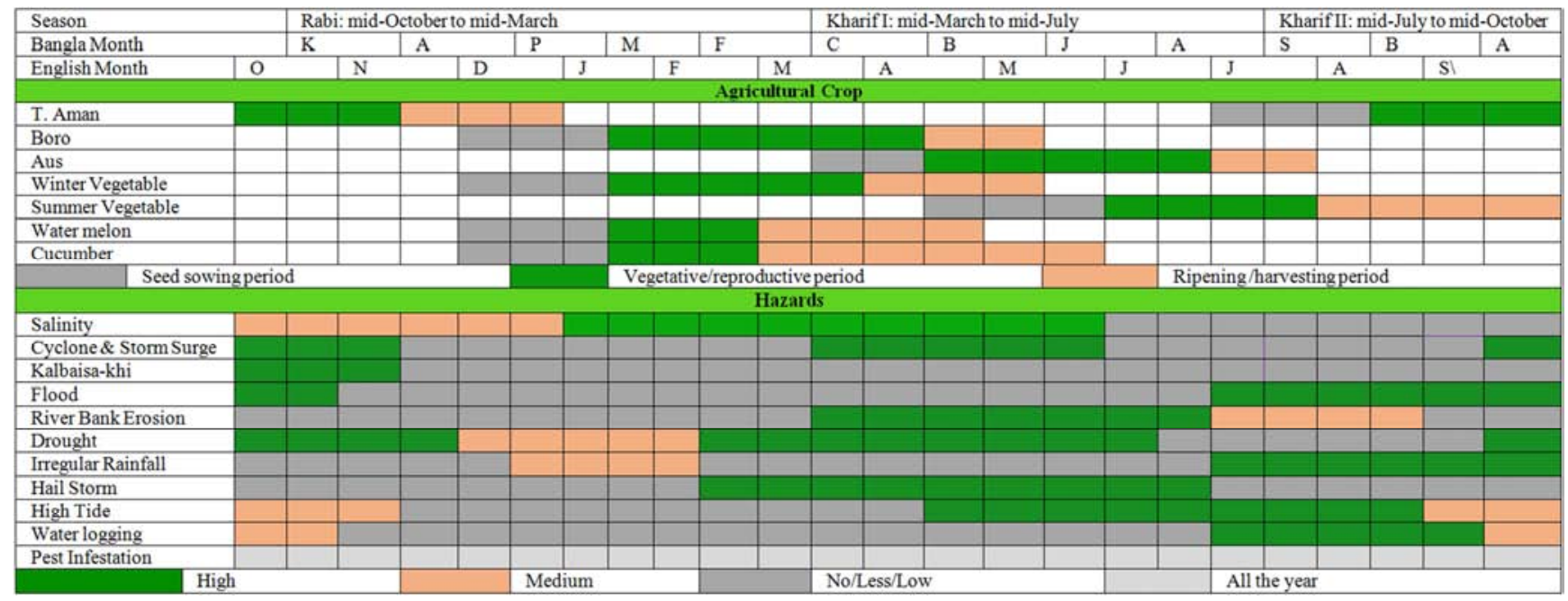

Figure 4. Livelihood and hazard seasonal calendar in the study area.

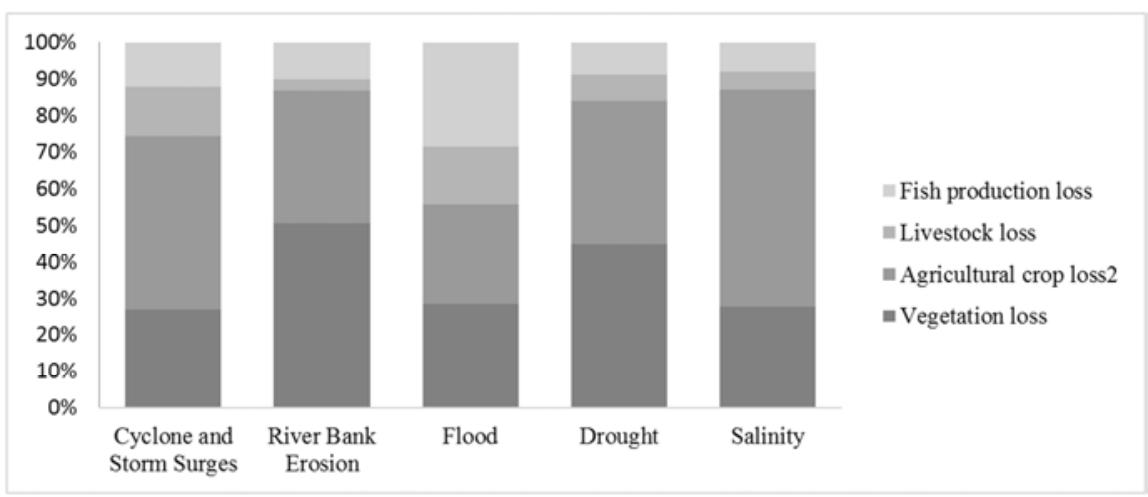

Figure 5. Climate change impact on agriculture sector. 


\subsection{Climate Change Impact on Agriculture}

The study found that the agricultural land use and cropping patterns of the study area are generally dominated by the rice crop and other crops suitable to the coastal and saline soil. The agricultural practices of the Char montaz is largely determined by the hydro-meteorological characteristics, geographical location and over all coastal features like soil and water salinity, tidal flow, upsurge (figure 5). As a consequence, a large portion of cultivable land remains either fallow or used for single crop. The main agricultural crops in the study area are Rice (T. Aman, Boro, Aus) which are cultivated in monsoon and winter season, Water melon and Cucumber which are cultivated in summer season and also some winter and summer vegetables (Papaya, Sweet Gourd, Red Pumping, Bitter Gourd).

From Focus Group Discussions, it is found that because of sea level rise ocean and river saline water enter into the crop land through interior cannel system and also in the time of any natural disaster like flood, cyclone, storm surge, heavy rainfall and high tide saline water enter into the crop land and thus increase soil salinity in the study area.

The main impacts of sea level rise on water resources are fresh water availability reduction by salinity intrusion. The main obstacle to intensification of crop production in Char montaz is seasonally high content of salts in the root zone of the soil. The salinity problem is very high in Char montazarea both in Kharif I (mid-March to mid-July) and Rabi (mid-October to mid-March) season. The high salinity problem in these season decrease crops production. In this period high salinity reduce the production of Karif I crops (Aus rice, summer vegetable) and Rabi crops (Boro, Water melon, Cucumber and winter vegetable). The salinity level is very high in Char montaz. The peoples live in Char montaz only can cultivate monsoon rice (T. Aman) because in the rainy season saline intensity is low and they can use rain water for cultivation and the rest of the year cultivated land became fallow. Most of the respondent said that the saline intensity gradually increase during last decade and mostly increase after SIDR and because of that high saline in the crop land they don't get much production according to their labor and that's why their economic loss increase. Due to production loss many farmer try to change their livelihood option and someone try to leave this region.

It is found that the people in the study area experienced with cyclone and cyclonic storm surge. According to the respondent, before the $21^{\text {st }}$ century the people in the study area face very few extreme cyclone and between the two big cyclone time interval is more than 15 years but in last 15 years they face three devastating cyclone like Sidr (2007), Aila (2009), Mahasen (2013). The people in the study area face cyclone mainly in two season (figure 6) in a yearseason one is mid-March to May (Kharif: I season) and the another season is mid-September to November (Kharif: II season). The people in the study area face cyclone Sidr in $15^{\text {th }}$ November 2007 and cyclone Mahasen in $15^{\text {th }}$ April
2013. In 2007 cyclone Sidr damage all the standing crops mainly T. Aman and in 2013 cyclone Mahasen also damage all standing crops including reproductive Aus and also damage some harvesting Boro rice and vegetable crops (questionnaire survey). Cyclone not only damage the agricultural crops but also destroyed whole environment including life loss, household damage, infrastructure damage, roads and embankment damage, communication destruction etc. that's make people become helpless (respondent opinion). The damage caused by cyclone is so many that's why people live in the study area feel very unsafe and try to migrate in the urban area for ensuring their livelihood.

In the study area during rainy season heavy rainfall and high tide water combine enter into the land area and occurred flood in the month of July to October (mid-Ashar to Kartik). Due to flood in this time the farmer in the study area cannot cultivate T. aman rice and sometimes they lost ripen/harvested Aus rice and also lost some summer vegetable like Sweet Gourd, Red Pumping, Bitter Gourd etc.

Drought mainly occurred in two season - season one is mid- February to mid- June (Falgun to Jaistha) and another season is mid- September to November (Ashwin to midAgrahayan) and medium drought occurred in December to mid- February (mid-Agrahayan to Magh). In this time farmer suffer more due to lack of irrigation water. Sometimes farmer face more difficulties to irrigate there Aus, water Melon and Cucumber land. During this time they collect irrigation water from river by using pump, but the river water is saline water. To avoid salinity problem sometimes farmer collect water from high tidal because low salt present in high tide than low tide, But it is difficult to maintain always. For this reason in this period they usually use saline water for irrigation purpose and that's why high saline in the crop land reduce the crop yield or sometimes farmer lost their crops and don't get much production according to their labor.

From the community peoples experience it is found that during the last decade in the study area rain occurred in late monsoon (mid- Ashar and sometimes at the end of Ashar) and maintain an irregular pattern of rainfall such as sometimes very high rain, sometimes low rain and sometimes no rain and sometimes it ends early (Shravan) and sometimes it ends late (Ashwin). Due to irregular rainfall farmer in the study area don't get water in early monsoon and for this reasone they suffer more for irrigation water and its increase production cost and sometimes they cannot cultivate T. Aman in proper time. Sometimes due to heavy rainfall in the end of the month Ashwin its create water logging or flood condition and that's why farmer lost their reproductive T. Aman rice. Irregular rainfall also reduce the production of some summer vegetable like Bitter Gourd.

Hail storm mainly occur in the month of mid- February to June. In this time the major standing crops in the study area are reproductive Boro, Water Melon, Cucumber and some vegetable crops. In these crops reproductive period hail storm hugely damage Water Melon and Cucumber and that's result is economic loss of farmer. 
In the month of April to August due to high tide in the river sometimes river water enter into the cultivated land and mostly in mid-June to August its create water logging in the crop land and for this reason farmer in the study area cannot cultivate their land and ultimately that land became useless in that season. Sometimes by interior cannel high tidal water enter into the Water Melon and Cucumber field and damage harvesting crops. From field survey it is found that due to river bank erosion the people in the study area suffer so much. In the study area river bank erosion occurred almost the year and the intensity of river bank erosion is very high in the rainy season. Due to river bank erosion people lost their agricultural and household land. From respondent opinion it is found that about $30 \%$ household those how live in the river side area forced to relocate or migrate the other side.

\subsection{Livelihood Adaptation Measures Taken by Local Community}

From the FGD it is found that to ensure/secure their livelihood local people diversified their works. Most of the people now increase their works, they do two, three or more works to earn money. Now farmer also catch fish in their off season or do both agriculture and fishing. Fisherman also involve with agriculture and small treading. Labor workers drive motorcycle, carrying van in dry season. It was found from community survey that after the two devastating cyclone Sidr and Aila about 35\% peoples were involved in two occupation (agriculture, fishing), about $25 \%$ involved in three occupation (agriculture, fishing, small treading); about 10\% involved in four occupation (agriculture labor, non agricultural wage labor, fishing, motorcycle driving) and some involved in five or more works to earn money or to secure their livelihood. About 20\% peoples in the study area are still now involve in one occupation. People who lost their maximum asset due to different climatic disaster, they migrate to another place. Details shown in following figure (figure 6).

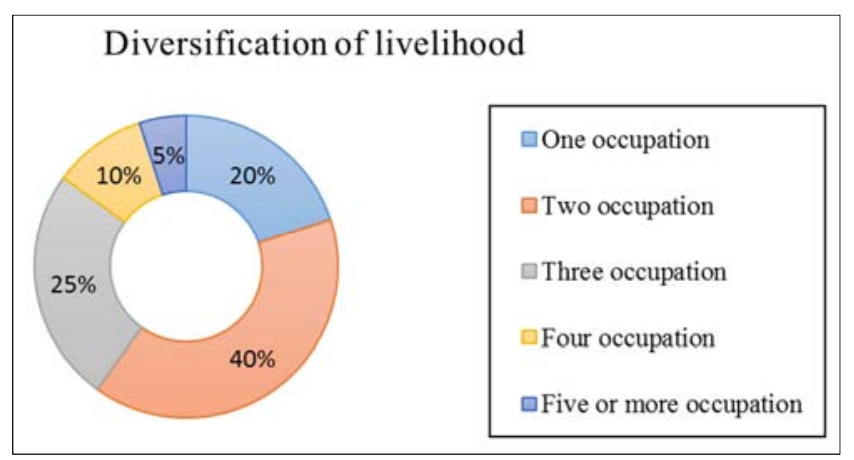

Figure 6. Livelihood diversification in the study area

As of other parts of rural Bangladesh women in the study areas are playing key roles in supporting their families by adopting several means. The women's in the study area are maintaining their livelihoods and trying to fulfill basic needs of their families through involvement in earth filling, homestead platform raising and planting vegetables in the raised plinths. They also nurture poultry and involved in beef fattening or rearing milky cow to generate income and reduce family poverty. As shelter problem is another problem created by frequent cyclones and storm surge. The cyclones affected women protect their houses through planting trees. They also cultivate vegetables on the raised platforms around their homesteads and store fuel woods. From the qualitative data, it is evident that women make and preserve the dry food like cake, chira, muri, khoi etc. during and pre disaster period. Thus the women try to give support to their family and also try to reduce their livelihood risks.

\section{Conclusion}

It is revealed that the main climatic hazards that damage the people's livelihood and put them in a difficult situation to meet the basic needs of the family members are mainly increase of climate change induced disasters. Seasonality (monsoon, dry season, cyclone season) also increased the vulnerability of extreme poor people by destroying their assets reducing their work opportunities, customer base and income. After the overall discussion, the study presents four major findings: 1) the climate has been changing over the last few decades in the Char Montaj; 2) due to climate change, livelihood patterns of that are also changing; 3) Sea level rise in Bay of Bengal and adjacent river (Bura Gauranga River) has caused severe environmental problems in the study area and increased salinity levels over the last few decades that caused severe reduction of agricultural crops in the study area; 4) Against climate change, the communities livelihood adaptation capacity for achieving sustainable livelihood are deficient, which further increase more vulnerability. It is also explored that these communities have very little knowledge on climate change and its future impacts. Most of them even do not know where they would move if their land ever submerge due to sea level rise. From the discussion it is also evident that the increase cyclone and cyclonic storm surge, monsoon flood has caused severe livelihood damage and migration of the peoples. Because of high tide and water logging peoples in the study area almost every year lost their productive lands. Therefore, taking this study as a model, a sector wise vulnerability map can be produced for the coastal areas of Bangladesh. This will eventually assist to produce a well-organized strategic plan enabling more efficient resource distribution among the impacted areas which would fulfill their actual need.

\section{References}

[1] Ahmed, A. U. and M. Alam, 1998. Development of climate change scenarios with general Circulation Models. In: S. Huq, Z. Karim, M. Asaduzzaman and F. Mahtab (Eds.). Vulnerability and Adaptation Climate Change for Bangladesh. Kluwer Academic Publication, Dordrecht. Pp: 13-20.

[2] Department Of Disaster Management. (2013) Training of Trainers (Tot) On Multi-Hazard Risk and Vulnerability Assessment (MRVA), Modeling and Mapping. Ministry Of Disaster Management and Relief, Government of Bangladesh. 
[3] IPCC (2007) Climate Change 2007: Impacts, Adaptation and Vulnerability: Contribution of Working Group II to the Fourth Assessment Report of the Intergovernmental Panel on Climate Change. In: Parry ML, Canziani OF, Palutikof JP, Van Der Linden PJ, Hanson CE (Eds) Cambridge University Press, Cambridge.

[4] Intergovernmental Panel on Climate Change (IPCC). Climate Change 2007: Impacts, Adaptation And Vulnerability: An Assessment Report Of The Intergovernmental Panel On Climate Change; Cambridge University Press: Cambridge, UK, 2007.

[5] Intergovernmental Panel on Climate Change, 2001, Climate Change 2001: Impacts, Adaptation and Vulnerability, Summery For Policymakers and Technical Summery of the Working Group II Report, Geneva.

[6] Islam, M. R., 2004. Living in the Coast: Problems, Opportunities and Challenges. Working Paper WP011, Dhaka. 2004, Programme Development Office (PDO) and Integrated Coastal Zone Management Plan (ICZMP). Pp: 13-15.

[7] Ministry Of Environment and Forest (Moef). (2009).
Bangladesh Climate Change Strategy Action Plan, 2009, Government of the People Republic of Bangladesh, Dhaka, Bangladesh.

[8] Nasreen, M. (1995) Coping With Floods: The Experience of Rural Women in Bangladesh, Unpublished Phd Dissertation, Messey University, New Zealand.

[9] Nasreen, M. (2008) 'Impact of Climate Change on Food Security in Bangladesh: Gender and Disaster Perspectives' Paper Presented At the 'International Symposium on Climate Change and Food Security in South Asia', Dhaka 25-30 August, 2008.

[10] Nasreen, M. (2008) Impact Of Climate Change on Agriculture and Food Security. Published By Action Aid International and Action Aid Bangladesh.

[11] Nasreen, M. (2008) 'Sustainable Development and Impacts of Climate Change: A Gender Perspective'. ITN, BUET.

[12] OXFAM (2009), Disaster Risk Reduction, Climate Change and Livelihood of the Poor and Marginalized People. A Framework for Oxfam GB Bangladesh. 